\title{
Lectinhistochemical detection of terminal carbohydrate residues in the enteric myxozoan Enteromyxum leei parasitizing gilthead seabream Sparus aurata (Pisces: Teleostei): a study using light and transmission electron microscopy
}

\author{
María J. Redondo and Pilar Alvarez-Pellitero \\ Instituto de Acuicultura de Torre de la Sal, Consejo Superior de Investigaciones Científicas, 12595 Ribera de Cabanes, Castellón, \\ Spain
}

\begin{abstract}
The presence of terminal carbohydrate residues in Enteromyxum leei (Diamant, Lom et Dyková, 1994) Palenzuela, Redondo et Álvarez-Pellitero, 2002 stages in gilthead seabream intestines was studied at light microscopy (LM) and transmission electron microscopy (TEM) level using lectin histochemical techniques. Abundant mannose and/or glucose residues were demonstrated by the intense staining caused by binding of biotinylated concanavalin A (Con A), at both LM and TEM. A clear positivity was also obtained with Ulex europaeus (UEA I) agglutinin specific for fucose residues. Both lectins stained E. leei proliferative and sporogonic stages, though glycan patterns varied between these developmental stages. Wheat germ agglutinin (WGA) and Bandeiraea simplicifolia lectin I (BSL I) recognised only structures in the sporogonic stages. Faint labelling occurred with Glycine max (SBA) lectin. No staining was obtained with Sambucus nigra (SNA) agglutinin. The TEM studies demonstrated a restricted presence of $\mathrm{N}$-acetyl-D-galactosamine and $\alpha$-D-galactose, whereas glucose/mannose and fucose, the dominant structures, were also present at the parasite membranes and host-parasite interface, suggesting a role in host-parasite interaction.
\end{abstract}

Key words: Myxosporea, lectins, lectin-gold electron microscopy, histochemistry

The phylum Myxozoa Grassé, 1970 includes a high number of species of which most are fish parasites. The relationships between myxozoans and their hosts do not often result in severe disease (Lom and Dyková 2006). However, worldwide, a number of species cause diseases which have an impact upon wild fish populations and farmed fish stocks. Among them, enteromyxoses caused by Enteromyxum spp. account for important epizootic episodes in farmed fish hosts (Ghittino et al. 2003, Golomazou et al. 2006, Quiroga et al. 2006). Enteromyxum leei (Diamant, Lom et Dyková, 1994) Palenzuela, Redondo et Álvarez-Pellitero, 2002 has been reported to infect numerous fish species (Padrós et al. 2001, Yaganida et al. 2004) and is one of the most serious threats for the culture of sparids (Palenzuela et al. 2006). This myxozoan resides mainly in the digestive tract, where the intestine is the principal target organ.

Recognition, a central event in a variety of biological phenomena, is frequently mediated by lectins, a class of proteins of non-immune origin that bind carbohydrates specifically and non-covalently. To elucidate the role of the lectin-carbohydrate binding in host-parasite interactions, thus far reported for few parasites (Jacobson and Doyle 1996, Xu et al. 2001), the knowledge of the surface-associated terminal carbohydrate residues in different developmental stages is essential. Such carbohydrate patterns have been studied only for few myxozoans (Muñoz et al. 1999, 2000, El-Matbouli et al. 2002, Morris and Adams 2004, Knaus and El-Matbouli 2005, Kaltner et al. 2007), including the enteric parasite Enteromyxum scophthalmi (Redondo et al. 2008) but not E. leei. In the present study, the terminal carbohydrate moieties in different stages of E. leei were identified and visualised by specific binding of plant lectins both with light microscopy (LM) and transmission electron microscopy (TEM).

\section{MATERIALS AND METHODS}

Infected gilthead seabream Sparus aurata L. were obtained from experimental infections with $E$. leei by cohabitation of recipient and donor fish and through waterborne contamination from the effluent of a tank containing infected fish. In these experiments, the water supply was filtered and UV-irradiated to avoid the entrance of other infections. Fish were sampled after 45-60 days of exposure. Control groups consisted of naïve fish not exposed to the parasite. Further details can be found in SitjàBobadilla et al. (2007). 
Table 1. Lectins used in this study: their acronyms, the concentration used, their sugar-binding specificities and the corresponding blocking sugars and their concentration. Abbreviations: Gal - galactose; GalNAc - N-acetyl-D-galactosamine; Glc - D-glucose; GlcNAc - N-acetyl-D-glucosamine; L-Fuc - L-fucose; Man - mannose; NeuNAc - N-acetylneuraminic acid; n/a: not applicable.

\begin{tabular}{|c|c|c|c|c|c|c|c|}
\hline \multirow[t]{2}{*}{ Acronym } & \multirow[t]{2}{*}{ Lectin source } & \multirow[t]{2}{*}{ Specificities } & \multicolumn{2}{|c|}{$\begin{array}{l}\text { Lectin concentration } \\
(\mu \mathrm{g} / \mathrm{ml})\end{array}$} & \multicolumn{2}{|c|}{ Blocking sugars } & \multirow{2}{*}{$\begin{array}{l}\text { Sugar } \\
\text { concen- } \\
\text { tration }(\mathrm{M})\end{array}$} \\
\hline & & & LM & TEM & LM & TEM & \\
\hline Con A & Canavalia ensiformis & $\begin{array}{l}\text { Man } \alpha-1>\text { Glc } \alpha-1> \\
\text { GlcNAc } \alpha-1\end{array}$ & 2 & 10 & $\begin{array}{l}\text { methyl- } \alpha-\mathrm{D}-\mathrm{Man}+ \\
\text { methyl- } \alpha-\mathrm{D}-\mathrm{Glc}\end{array}$ & methyl- $\alpha$-D-Man & 0.2 \\
\hline UEA I & Ulex europaeus & $\begin{array}{l}\text { L-Fuc } \alpha 1,2 \mathrm{Gal} \beta 1,4 \\
\text { GlcNAc } \beta 1,6\end{array}$ & 20 & 20 & L-Fuc $\alpha$ & L-Fuc $\alpha$ & 0.2 \\
\hline WGA & Triticum vulgaris & $\begin{array}{l}\text { GlcNAc } \\
(ß 1,4 \mathrm{GlcNAc})_{1-2}> \\
ß 1,4 \mathrm{GlcNAc}>\text { NeuNAc }\end{array}$ & 10 & $\mathrm{n} / \mathrm{a}$ & GlcNAc $\alpha$ & $\mathrm{n} / \mathrm{a}$ & $0.5 / 0.2$ \\
\hline SBA & Glycine max & Terminal $\alpha, \beta$ GalNAc $>\alpha, \beta$ Gal & 5 & 20 & GalNAc $\alpha$ & GalNAc $\alpha$ & 0.2 \\
\hline BSL I & Griffonia simplicifolia & D-Gal $>$ D-GalNAc & 5 & $\mathrm{n} / \mathrm{a}$ & $\mathrm{Gal}+\mathrm{GalNAc} \alpha$ & $\mathrm{n} / \mathrm{a}$ & 0.2 \\
\hline SNA & Sambucus nigra & $\begin{array}{l}\text { NeuAc } \alpha 2,6 \mathrm{Gal}= \\
\text { NeuAc } \alpha 2,6 \mathrm{GalNAc}\end{array}$ & 20 & $\mathrm{n} / \mathrm{a}$ & NeuNAc & $\mathrm{n} / \mathrm{a}$ & 0.2 \\
\hline
\end{tabular}

Fish were killed by overdose of MS222 and bled from the caudal vein before the necropsy. Samples of the digestive tract of infected fish were fixed and processed for LM and TEM (see below). To select the tissue samples for histochemical studies, Technovit 7100 resin (Kulzer, Heraeus, Germany) sections were also obtained and infection intensity was evaluated following a scale of $1+$ to $6+$, according to the relative numbers of parasites present in the studied tissues. Fish with medium/high intensity of infection (4+ to $6+)$ were selected for this study.

For lectin histochemistry at LM, tissue portions of the digestive tract were fixed in $10 \%$ buffered formalin and embedded in paraffin for histological processing, following standard histology procedures. Sections ( $4 \mu \mathrm{m}$ thick) were collected on Super Frost-plus microscope slides (Menzel-Glaser, Germany) without additives and allowed to dry overnight. Slides were deparaffinised and hydrated and the endogenous peroxidase activity was blocked by incubation in $0.3 \%(\mathrm{v} / \mathrm{v})$ hydrogen peroxide for $30 \mathrm{~min}$. After rinsing with TTBS ( $20 \mathrm{mM}$ Tris- $\mathrm{HCl}, 0.5 \mathrm{M} \mathrm{NaCl}$, pH 7.2 containing $0.05 \%$ Tween 20 ), sections were incubated with biotinylated lectin solutions in TTBS, for $1 \mathrm{~h}$ at $20^{\circ} \mathrm{C}$. After rinsing, the sections were incubated with the avidin-biotinperoxidase complex (ABC, Vector Laboratories, Burlingame, CA, USA) for $30 \mathrm{~min}$ at $20^{\circ} \mathrm{C}$ and finally, bound peroxidase was visualised by addition of DAB chromogen (3,3'-diaminobenzidine tetrahydrochloride) (Sigma, St. Louis, MO, USA) for $5 \mathrm{~min}$. The reaction was stopped with deionised water and the sections were counterstained using Gill's haematoxylin and mounted in di- $N$-butyl-phthalate in xylene. Incubation of ABC with the tissue sections alone served as control to discard the presence of endogenous biotin-binding proteins. Each lectin and its corresponding blocking sugar $(0.2 \mathrm{M})$ were incubated for $1 \mathrm{~h}$ at $20^{\circ} \mathrm{C}$, before applying to the sections as binding specificity controls. The concentrations of the lectins used (obtained from Sigma or Vector), their acronyms, major sugar specificities and blocking sugars used are listed in Table 1.

For TEM studies, samples were fixed at $4{ }^{\circ} \mathrm{C}$ in $0.1 \mathrm{M}$ cacodylate buffer $\mathrm{pH} 7.2$, containing $2.5 \%(\mathrm{v} / \mathrm{v})$ glutaraldehyde and embedded in Spurr's resin (details in Redondo et al. 2008). Grids were incubated with blocking buffer $(2 \%$ bovine serum albumin, BSA) in $10 \mathrm{mM}$ Hepes $\mathrm{pH} 7.5$ ) at $20^{\circ} \mathrm{C}$ for $30 \mathrm{~min}$ and then with biotinylated lectins at $20^{\circ} \mathrm{C}$ for $1 \mathrm{~h}$. Parasite-infected tissues were tested with the lectins which gave the clearest positive results at light microscope. All the lectins were used following the manufacturer's recommendations. BSL I and SBA (Vector) were diluted in a buffer containing $1 \%$ BSA in $10 \mathrm{mM}$ Hepes, $0.15 \mathrm{M} \mathrm{NaCl}$ and $0.1 \mathrm{mM} \mathrm{CaCl}_{2} \mathrm{pH} 7.5$, whereas Con A (Vector) and WGA (Sigma) were prepared in $0.1 \mathrm{M} \mathrm{PBS,}$ $\mathrm{pH} 7.4$ containing $2 \%$ BSA. After washing $(4 \times 5 \mathrm{~min})$ using buffers described above, grids were incubated with streptavidin conjugated with $15 \mathrm{~nm}$ colloidal gold particles (British Biocell International Ltd, Cardiff, UK) diluted 1:25 in $10 \mathrm{mM}$ Hepes $\mathrm{pH} 7.5$, for $1 \mathrm{~h}$ at $20^{\circ} \mathrm{C}$. As controls for binding specificity, each lectin and its corresponding blocking sugar $(0.2 \mathrm{M})$ (Table 1) were incubated overnight at $4{ }^{\circ} \mathrm{C}$ before applied to the grids. Negative controls were obtained using buffers described above without lectins in the first incubation step. Grids were washed with $10 \mathrm{mM}$ Hepes and bidistilled water, and stained with uranyl acetate and lead citrate. They were examined in a JEOL-1010 MET operating at $80 \mathrm{kV}$.

\section{RESULTS}

\section{LM observations}

Con A produced a strong label in E. leei proliferative stages, mainly in secondary (S) cells and less intensively in tertiary $(\mathrm{T})$ cells, whereas the reactivity was slighter in several spore structures (Fig. 1). A distinct signal was produced by UEA $\mathrm{I}$ in the $\mathrm{S}$ cells of proliferative stages and the accompanying cells of sporoblasts (Fig. 2). No staining reaction occurred in proliferative stages with WGA, whereas some spore structures, but not the polar capsules, were stained with this lectin (Fig. 3). SBA reacted intensely with spores (Fig. 4), but not with the accompanying cells of the sporoblasts and the proliferative stages (Figs. 5-6). Staining intensity for BSL I-reactive carbohydrate residues was only weak in some spore structures (Fig. 7), whereas the mature polar capsules were negative (Fig. 8). SNA did not recognise any parasite structure (Fig. 9). Lectin staining was inhibited after blocking with the respective specific sugar in all cases. Control reactions (see M\&M) were negative. The LM staining patterns of E. leei are summarised in Table 2. 

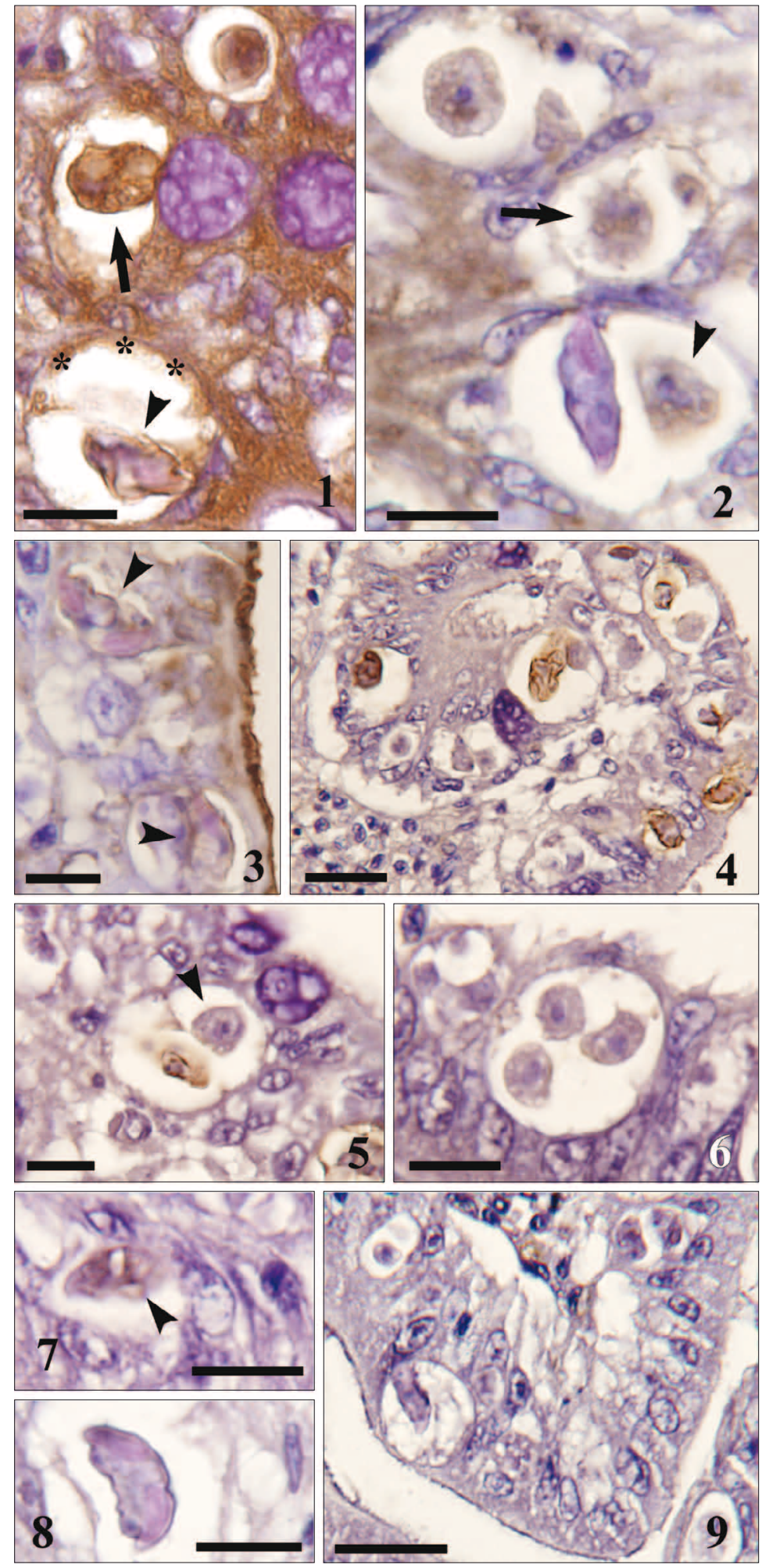

Figs. 1-9. Light micrographs of Enteromyxum leei-parasitized gilthead seabream intestines in paraffin sections stained with biotinylated lectins. Fig. 1. Con A lectin. Evident binding to secondary (S) and tertiary (T) cells in a proliferative stage (arrow). Some spore structures (arrowhead) and the enveloping primary $(\mathrm{P})$ cell in sporoblast $(*)$ are also stained. Fig. 2. UEA I lectin. Binding at $\mathrm{S}$ cell of a proliferative stage (arrow). Note the absence of reactivity at the spore and the positive staining in the accompanying cell (arrowhead) of a sporogonic stage. Fig. 3. WGA lectin. Slight staining at spores (arrowheads). Figs. 4-6. SBA lectin. Some spore structures are positive (Figs. 4, 5), whereas no staining was detected in accompanying cells (Fig. 5, arrowhead) and proliferative stages (Fig. 6). Figs. 7, 8. BSL I lectin. Spores are slightly stained at the valves (arrowhead) (Fig. 7) but other structures are negative (Fig. 8). Fig. 9. SNA lectin. Absence of reactivity at parasitic stages. Scale bars: Figs. 1-3, 5-8=10 $\mu \mathrm{m}$; Figs. 4, $9=20 \mu \mathrm{m}$. 


\section{TEM observations}

Using biotinylated Con A, proliferative stages of E. leei were clearly labelled in the cytoplasm and mitochondria of primary (P), S and T cells (Figs. 10-12), and in the nucleus (Fig. 11) and nucleolus of the S cell. Few grains were also detected in the adjacent host $(\mathrm{H})$ cell and nearby the contact surface of P cell and H cell (Fig. 10). In sporoblasts (Fig. 13), some grains were observed in the cytoplasm of the P cell and in the rough endoplasmic reticulum (rER), the lysosomes (Fig. 15) and the mitochondria (Fig. 14) of accompanying cells. Labelled spore structures included polar capsules, the cytoplasm of capsulogenic and valvogenic cells (Fig. 16), and the cytoplasm and mitochondria of the sporoplasmic cell (Fig. 17). With UEA I, a faint binding reaction was observed at the P cell-H cell interface (Fig. 18), the cytoplasm and mitochondria of $\mathrm{P}$ and $\mathrm{S}$ cells, the $\mathrm{P}-\mathrm{S}$ cell contact, and the nucleus (including the nucleolus of the $\mathrm{S}$ cell) in proliferative stages (Figs. 18, 19). Some label was also detected in the joining H cell (Fig. 18). In sporogonic stages (Fig. 20), grains were seen in the enveloping P cell (Figs. 21, 22), the cytoplasm, mitochondria and nucleus of valvogenic (Figs. 22, 23) and capsulogenic (Figs. 23, 24) cells, and the cytoplasm and nucleus of sporoplasmic cell (Fig. 25). Polar capsule and polar filament were also labelled (Fig. 26). SBA showed a weak reactivity in the proliferative stages. Positive were the mitochondria of P cells and the cytoplasm of S and T cells. In sporogonic stages, only the polar capsules were slightly reactive (images not shown). The TEM binding patterns of proliferative and sporogonic stages of E. leei are summarised in Tables 3 and 4, respectively. All controls resulted negative for immunogold labelling.

\section{DISCUSSION}

Enteromyxum leei stages were stained with several lectins, as visualised by LM and TEM. Mannose and/or glucose residues of carbohydrate structures were more abundant in proliferative than sporogonic stages and spores, as demonstrated by Con A staining at LM. This staining pattern resembles that observed for Enteromyxum scophthalmi Palenzuela, Redondo et Álvarez-Pellitero, 2002 (Redondo et al. 2008). Mannose/glucose moieties are the most frequent carbohydrate residues recognised by lectins in myxozoans. Con A stained the spores of 11 out of 12 myxosporeans probed by Muñoz et al. (1999), and the extrasporogonic stages of Tetracapsuloides bryosalmonae (Canning, Curry, Feist, Longshaw et Okamura, 1999) Canning, Tops, Curry, Wood et Okamura, 2002 (PKX) from the kidney of rainbow trout (Castagnaro et al. 1991, Morris and Adams 2004). Mannose-containing carbohydrate residues were also demonstrated in the spores of Myxobolus cerebralis Hofer, 1903 by staining with Con A, Lens culinaris agglutinin (LCA) and Pisum sativum agglutinin (PSA). Labelling was stronger in
Table 2. Lectin-binding patterns found in spores and proliferative stages of Enteromyxum leei as observed in paraffin sections at LM. PC - polar capsules; $\mathrm{S}$ - secondary cell; $\mathrm{T}$ - tertiary cell. Intensity of staining: +++ strong; ++ moderate; + weak; +/- traces; - none.

\begin{tabular}{lccc}
\hline Lectin & $\begin{array}{c}\text { Proliferative } \\
\text { stages }\end{array}$ & \multicolumn{2}{c}{ Sporogonic stages } \\
\cline { 3 - 4 } & & PC & Other structures \\
\hline Con A & +++ & ++ & ++ \\
& $(\mathrm{S}, \mathrm{T})$ & & + \\
UEA I & + & - & + \\
& $(\mathrm{S})$ & & (accompanying S) \\
WGA & - & - & +- \\
SBA & - & + & ++ \\
BSL I & - & - & + \\
SNA & - & - & - \\
\hline
\end{tabular}

Table 3. Lectin-binding patterns found in proliferative stages of Enteromyxum leei at TEM. P - primary cell; S - secondary cell; $\mathrm{T}$ - tertiary cell; $\mathrm{H}$ - host cell. Intensity of label: ++ moderate; + weak; - none.

\begin{tabular}{lccc}
\hline Structure labelled & Con A & UEA I & SBA \\
\hline P/H contact junction & + & + & - \\
Parasite membranes & - & + & - \\
\multirow{2}{*}{ Nucleus } & + & P/S & \\
& S & S & - \\
Nucleolus & + & + & - \\
Mitochondria & $\mathrm{S}$ & $\mathrm{S}$ & \\
& + & + & + \\
Cytoplasm matrix & $\mathrm{P}, \mathrm{S}, \mathrm{T}$ & $\mathrm{P}, \mathrm{S}$ & $\mathrm{P}$ \\
& ++ & $\mathrm{P}+$ & + \\
& $\mathrm{P}, \mathrm{S}, \mathrm{T}$ & $\mathrm{S}++$ & $\mathrm{S}, \mathrm{T}$ \\
\hline
\end{tabular}

Table 4. Lectin-binding patterns found in sporogonic stages of Enteromyxum leei at TEM. P-VC - interface between primary cell and valvogenic cell. Intensity of label: + weak; - none.

\begin{tabular}{llccc}
\hline Structure labelled & & Con A & UEA I & SBA \\
\hline Valvogenic cell & P-VC & - & - & - \\
& Cytoplasm matrix & + & + & - \\
& Nucleus & - & + & - \\
& Mitochondria & - & + & - \\
Capsulogenic cell & Cytoplasm matrix & + & + & - \\
& Nucleus & - & + & - \\
& Mitochondria & - & + & - \\
& Polar capsule & + & + & + \\
& Polar filament & + & + & - \\
Sporoplasmic cell & Cytoplasm matrix & + & + & - \\
& Mitochondria & + & - & - \\
& Nucleus & + & + & - \\
Accompanying cell & Endoplasmic reticulum & + & - & - \\
& Lysosomes & + & - & - \\
& Mitochondria & + & - & - \\
\hline
\end{tabular}

myxospores from trout and actinospores from the tubificid worm than in free actinospores (Kaltner et al. 2007). The present TEM study confirmed a Con A binding pattern of E. leei stages in the cytoplasm of $\mathrm{P}, \mathrm{S}$ and T cells of proliferative stages and in some spore structures. This pattern is quite similar to that obtained for E. scophthalmi 

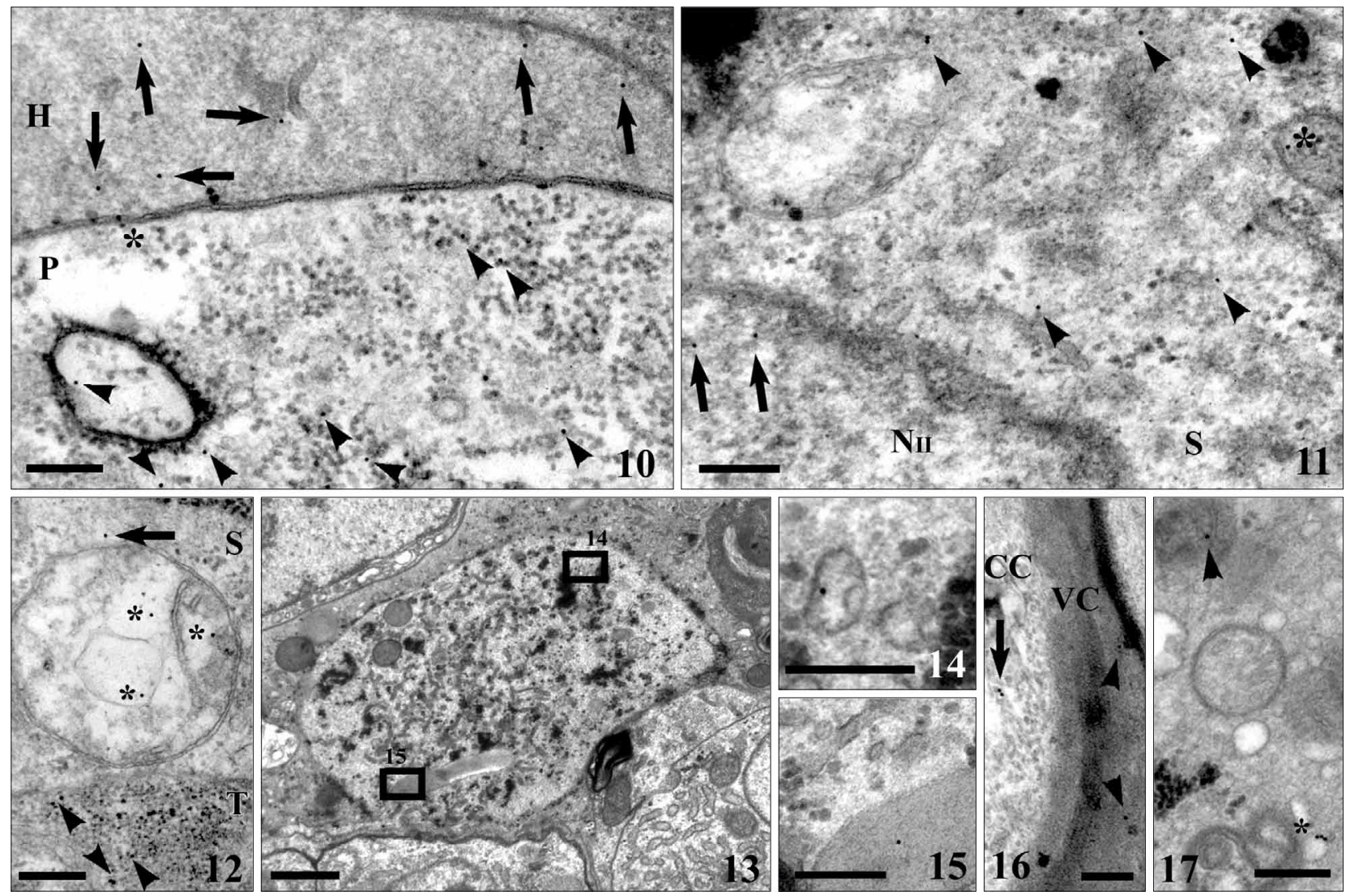

Figs. 10-17. Transmission electron micrographs of Enteromyxum leei-infected gilthead seabream intestines embedded in Spurr's resin and treated with gold-conjugated Con A lectin. Figs. 10-12. Proliferative stages. Fig. 10. Scattered gold grains at the parasites' primary $(\mathrm{P})$ cell (arrowheads), host $(\mathrm{H})$ cell (arrows) and the interface between the P cell and the H cell $(*)$. Fig. 11. Labels at the secondary (S) cell cytoplasm (arrowheads), mitochondria $(*)$ and nucleus $\left(\mathrm{N}_{\mathrm{II}}\right)$ (arrows). Fig. 12. Scattered marks at the $\mathrm{S}$ cell cytoplasm (arrow) and mitochondria $(*)$, and at the tertiary $(\mathrm{T})$ cell cytoplasm (arrowheads). Fig. 13. Panoramic view of sporogonic stage. Figs. 14-16. Details of the binding sites at mitochondria (Fig. 14), lysosomes (Fig. 15) of an accompanying cell, and capsulogenic (arrow) and valvogenic (arrowheads) cells (Fig. 16). Fig. 17. Marks at mitochondria (*) and cytoplasm (arrowhead) of the sporoplasmic cell in a spore. Scale bars: Figs. $10-12,14-17=0.25 \mu \mathrm{m}$; Fig. $13=1 \mu \mathrm{m}$.

proliferative stages (Redondo et al. 2008). Labelling with Con A was also observed by TEM in sporogonic stages of Sphaerospora dicentrarchi Sitjà-Bobadilla et ÁlvarezPellitero, 1992, Polysporoplasma sparis Sitjà-Bobadilla et Álvarez-Pellitero, 1995 and Leptotheca sp. (Muñoz et al. 2000), and in T. bryosalmonae (mainly in the cytoplasm of $\mathrm{P}$ and $\mathrm{S}$ cells and some vacuolar structures) (Morris and Adams 2004).

Both proliferative and sporogonic stages of E. leei were slightly labelled with UEA I at LM, and the staining pattern was similar to that observed in E. scophthalmi (Redondo et al. 2008). Scarce or no staining with this lectin was found in other myxozoans. Muñoz et al. (1999) reported staining with UEA I only in the polar capsules of Leptotheca sp. (1 out of 12 species assayed), and no labelling was detected in Sphaerospora sp. from Salmo trutta (Marín de Mateo et al. 1997) and T. bryosalmonae (PKX) (Castagnaro et al. 1991, Morris and Adams 2004). In $M$. cerebralis, UEA I stained only and slightly the actinospores from the tubificid worm (Kaltner et al. 2007).
TEM allowed to localise binding sites of fucose residues in the $\mathrm{P}$ and $\mathrm{S}$ cells of proliferative stages and in the different spore structures of $E$. leei. No ultrastructural data on UEA labelling of other myxozoans are available for comparison.

Two lectins recognising galactose and N-acetylgalactosamine residues, SBA and BSL I, were used in this study. At LM, SBA labelled only sporogonic stages of $E$. leei, though a weak signal was detected at TEM in proliferative stages. By contrast, with this lectin, each of the E. scophthalmi stages showed a distinct staining pattern (Redondo et al. 2008). Sphaerospora sp. was also marked by SBA (Marín de Mateo et al. 1997) whereas only a weak label was obtained by Muñoz et al. (1999) in S. dicentrarchi, Leptotheca sp. and Kudoa sp. Different staining intensities with SBA have been reported in T. bryosalmonae (PKX) at LM (Castagnaro et al. 1991, Marín de Mateo et al. 1996, Morris and Adams 2004), and a scant mark, reduced to certain vacuolar structures in the P cell, was detected at TEM (Morris and Adams 2004). 
BSL I stained weakly some structures of E. leei proliferative stages at LM. The label with this lectin was also faint in E. scophthalmi, though the ultrastructural study confirmed the binding to P cells and to some spore structures including the sporoplasm (Redondo et al. 2008). BSL I stained the polar capsules or the valves of only 3 out of 12 species tested by Muñoz et al. (1999), though binding to Zschokkella mugilis Sitjà-Bobadilla et Álvarez-Pellitero, 1993 and Leptotheca sp. developmental stages was demonstrated in an ultrastructural study (Muñoz et al. 2000). Pre-sporogonic and extrasporogonic stages of $T$. bryosalmonae were strongly stained with GSI-I (= BSL I) at LM (Castagnaro et al. 1991, Marín de Mateo et al. 1996, Morris and Adams 2004), though only weak labelling of some vacuolar structures in the P cell was seen at TEM (Morris and Adams 2004). Interestingly, the myxospores and actinospores of $M$. cerebralis, but not the free actinospores from the tubificid worm, were strongly stained with GSI-I (Kaltner et al. 2007).

WGA (binding to GlcNAc and neuraminic acid) stained only and faintly the sporogonic stages of E. leei at LM. In E. scophthalmi, labelling with this lectin was somewhat more intensive and the developmental stages were also marked, though slightly (Redondo et al. 2008). In contrast, WGA labelled different structures of several myxozoans. The polar capsules were recognised in all positive myxosporeans (10 out of 12) assayed by Muñoz et al. (1999). In T. bryosalmonae (PKX), weak to moderate binding patterns, applying both LM and TEM, were reported (Castagnaro et al. 1991, Morris and Adams 2004), whereas Sphaerospora sp. was inconsistently stained (Marín de Mateo et al. 1997). The spores of M. cerebralis were clearly reactive for WGA (Kaltner et al. 2007). No staining of $E$. leei proliferative or sporogonic stages was detected with SNA lectin, as described for E. scophthalmi (Redondo et al. 2008) and M. cerebralis (Kaltner et al. 2007). Muñoz et al. (1999), reported SNA binding only in Polysporoplasma sparis and Kudoa sp. The absence of SNA (specific for NeuAca $(2,6) \mathrm{Gal} / \mathrm{GalNac}$ ) labelling could indicate that WGA detected GlcNAc or its polymers in E. leei. A protective role of chitin, a polymer of GlcNAc, has been suggested for other myxozoans (Lukeš et al. 1993, Muñoz et al. 2000). However, more specific studies are necessary to demonstrate the presence of chitin in E. leei and the possible involvement of the terminals recognised by WGA in protection or other functions.

The glycan pattern and/or staining intensity may vary between $E$. leei developmental stages. A differential expression of sugars according to the life-cycle stage has also been described for the myxozoans E. scophthalmi (Redondo et al. 2008), T. bryosalmonae (Morris and Adams 2004) and M. cerebralis (Kaltner et al. 2007), and moreover for other parasites (Schabussová et al. 2003, Hammerschmidt and Kurtz 2005, Kaltner et al. 2007).
Glycosylation can change in response to extracellular stimuli (Iyer and Hart 2003) and thus can play a significant role in pathogenesis of infection. Ultrastructural studies can help to elucidate the glycosylation patterns of the different cell structures and the putative role of carbohydrate residues in the parasite biology and the hostparasite relationship. However, information obtained at the ultrastructural level can be limited by technical constraints, as some lectins with no labelling in immunogold studies can show strong staining using lectin histochemistry (Griffiths 1993). In spite of the technical limitations, some data have been obtained for myxozoan carbohydrate patterns at TEM. Several carbohydrate residues were detected by lectin binding at the contact surface of myxozoan cell and host cell, as well as in membranes, mitochondria, rER and nucleus in the current study on E. leei, and some scarce data are also available for other myxozoans. In eukaryotes, different routes of glycosylation take place in these cellular compartments (Hart and West 2009). The presence of glucose/mannose and fucose residues in the $E$. leei-host cell junction suggests their role in the host-parasite interaction. Terminal glucose/mannose residues were also dominant in the parasite membrane and the host-parasite interface in E. scophthalmi (Redondo et al. 2008) but were scant in the T. bryosalmonae plasmalemma (Morris and Adams 2004). In E. leei, glucose/ mannose and fucose residues appeared also in the mitochondria and the nucleus of several cell types and in the rER of the sporogonic accompanying cell. Glucose/mannose were detected in the mitochondria and nucleus of E. scophthalmi S cell (Redondo et al. 2008) and Leptotheca sp. capsulogenic cell (Muñoz et al. 2000). The high prevalence of the mannose residues is a characteristic of carbohydrates in many pathogenic organisms (Taylor et al. 1986, Horák 1995, Fuchs et al. 1999, Kim et al. 1999, Klabunde et al. 2000, Casaravilla et al. 2003, Taupin et al. 2006). It is also well known that terminal mannose moieties play a significant role in the host-parasite interaction (Soeiro et al. 1999, Fuller and McDougal 2002), and their recognition by specific receptors (i.e. mannose-binding lectin) can trigger a host immune response in parasitic diseases (Barbosa et al. 1992, Wisnewski et al. 1993, Kim et al. 1999, Klabunde et al. 2000, Gruden-Movsesijan and Milosavljevic 2006). Fucose residues were, by contrast, scarcely or not found in other myxozoans. However, a clear presence of terminal $\alpha$-linked fucose moieties has been described in several protozoan and helminth parasites (Wisnewski et al. 1993, Benchimol and Bernardino 2002, Schabussová et al. 2003, Hokke and Yazdanbakhsh 2005). Fucosylated carbohydrate structures are involved in a variety of biological and pathological processes, including the adhesion and invasion of microorganisms, and they are known to have immunological relevance in hostparasite interactions (Wisnewski et al. 1993, John et al. 


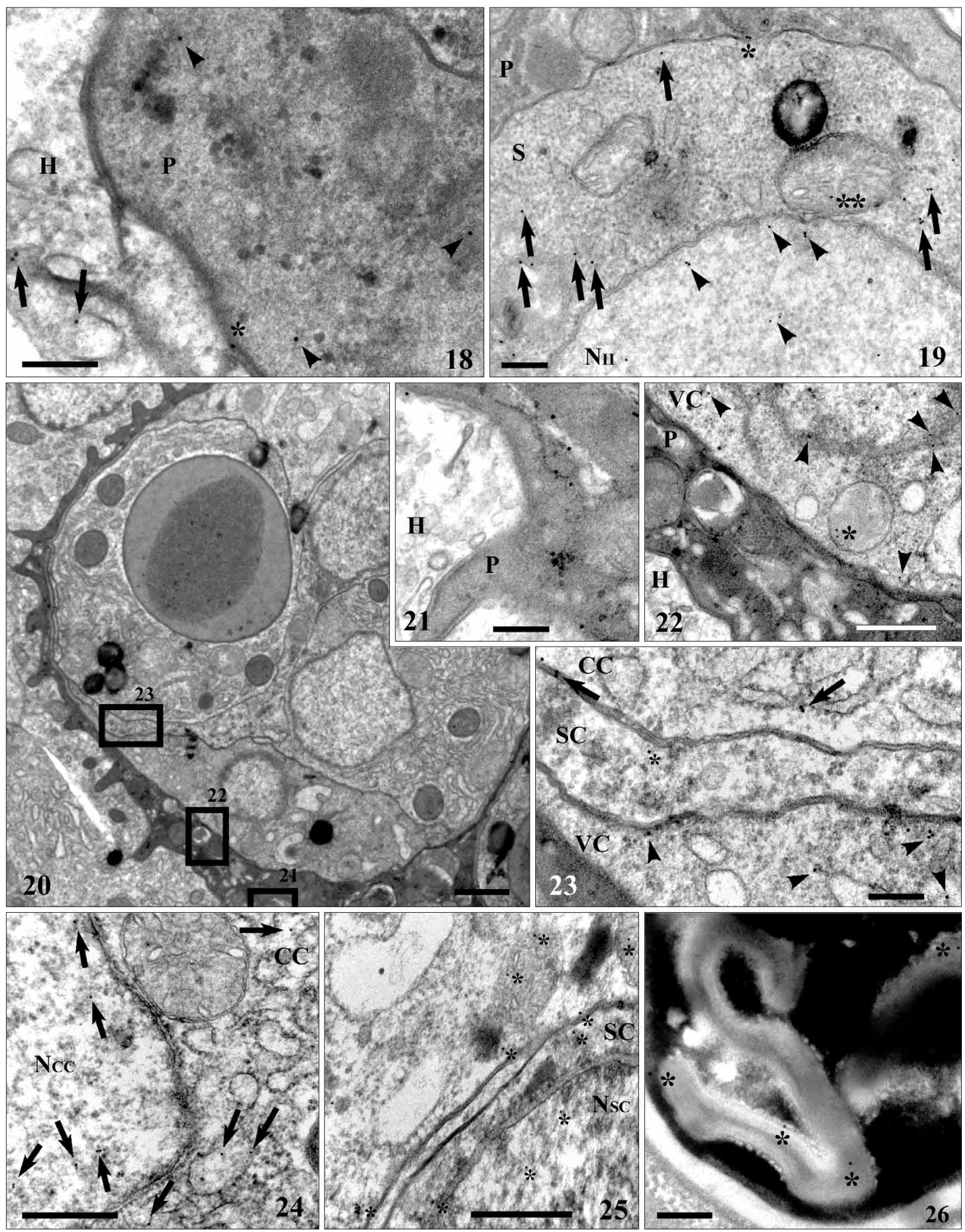

Figs. 18-26. Transmission electron micrographs of Enteromyxum leei-infected gilthead seabream intestines embedded in Spurr's resin and treated with gold-conjugated UEA I lectin. Figs. 18, 19. Proliferative stages. Fig. 18. Scattered gold grains at the parasite primary $(\mathrm{P})$ cell (arrowheads), the interface between $\mathrm{P}$ and host $(\mathrm{H})$ cells $\left(^{*}\right)$ and the H cell (arrows). Fig. 19. Several gold grains at the contact between $\mathrm{P}$ and secondary $(\mathrm{S})$ cells $(*)$, and the $\mathrm{S}$ cell cytoplasm (arrows), mitochondria $(* *)$, and nucleus $\left(\mathrm{N}_{\mathrm{II}}\right)($ arrowheads). Fig. 20. Panoramic view of a maturing spore. Figs. 21-23. Details of the binding sites at the enveloping P cell (Figs. 21, 22), the cytoplasm (arrowheads) and mitochondria (*) of the valvogenic cell (VC) (Fig. 22), and the cytoplasm of capsulogenic cell (CC) (arrows), sporoplasmic cell (SC) $(*)$ and VC (arrowheads) (Fig. 23). Figs. 24-26. Labelling pattern of a spore. Note the binding sites at the cytoplasm and nucleus (Ncc) of a CC (arrows) (Fig. 24), an SC (*) (Fig. 25), and the polar capsule and polar filament (*) (Fig. 26). Scale bars: Figs. 18, 19, 21, 23, $26=0.2 \mu \mathrm{m}$; Figs. 20, 22, 24, $25=5 \mu \mathrm{m}$ 
1999, Ma et al. 2006, Imberty and Varrot 2008). Galactose and GalNAc, which are among the carbohydrate residues more frequently involved in the host-parasite interaction (Jacobson and Doyle 1996), were not abundant in E. leei, and were not found at the host-parasite interface. However, galactose/GalNAc were present at this location in other myxozoans, such as T. bryosalmonae (Morris and Adams 2004) and E. scophthalmi (Redondo et al. 2008). Galactose and/or GalNAc residues were also detected in the mitochondria and nuclei of some cells in proliferative stages of E. scophthalmi (Redondo et al. 2008) and Z. mugilis (Muñoz et al. 2000). These carbohydrate residues were also present in the nuclei of other parasites, such as Tritrichomonas foetus (Benchimol and Bernardino 2002).

Consequently, some carbohydrate structures identified in E. leei are also present in other myxozoans, mainly in developmental stages of the congeneric E. scophthalmi. Glucose/mannose moieties are, compared to other carbohydrate epitopes, more frequently and intensely recognised in the myxozoans studied thus far, and they are present at the host-parasite interface in both enteromyxoses. Differences between both Enteromyxum spp. concern mainly the higher presence of GalNac/Gal in E. scophthalmi, as demonstrated by the SBA staining patterns, and the intensity and type of structures stained with labelled lectins, such as UEA I and WGA. The observed glycosidic patterns suggest that terminal carbohydrate residues in E. leei could be recognised by lectins present in the fish host. Among those lectins recognising the terminals present in the E. leei-fish intestine contact, a fucose-binding lectin has been characterised from gilthead seabream (Cammarata et al. 2007) and a mannose receptor has been suggested to be involved in non-specific recognition and phagocytosis by this fish (Rodríguez et al. 2003).

The current study has demonstrated the presence of specific carbohydrate patterns in E. leei. The location of some carbohydrate residues at the parasite-host interface or in certain parasite cell organelles suggests their role in the parasite biology and host-parasite relationships. Thus, the functional aspects of the interactions of such carbohydrate terminals with the host deserve further attention. Recent findings have highlighted the importance of carbohydrate interactions in bacterial infections of experimental animals and their potential use in anti-adhesion therapies (Ma et al. 2006, Sharon 2006). This could be also a promising approach in the treatment of enteromyxoses in fish.

Acknowledgements. Funding for this work was obtained from the Spanish Ministry of Science and Education through the research project AGL2006-13158-C01. M. J. Redondo is recipient of a CSIC I3P contract funded by the European Social Fund. We are thankful to Mr. J. Monfort and to "Serveis Cientificotècnics" of the Universities of Barcelona and Valencia for LM and TEM processing, respectively.

\section{REFERENCES}

Barbosa H.S., Nazareth M., Meirelles S.L. 1992: Ultrastructural detection in vitro of WGA-, RCAI-, and Con A-binding sites involved in the invasion of heart muscle cells by Trypanosoma cruzi. Parasitol. Res. 78: 404-409.

Benchimol M., Bernardino M.V. 2002: Ultrastructural localization of glycoconjugates in Tritrichomonas foetus. Parasitol. Res. 88: $134-143$.

Cammarata M., Benenati G., Odom E.W., Salerno G., Vizzini A., Vasta G., Parrinello N. 2007: Isolation and characterization of a fish F-type lectin from a gilt head bream (Sparus aurata) serum. Biochim. Biophys. Acta 1770: 150-155.

Casaravilla C., Malgor R., Carmona C. 2003: Characterization of carbohydrates of adult Echinococcus granulosus by lectinbinding analysis. J. Parasitol. 89: 57-61.

Castagnaro M., Marín De Mateo M., Ghittino C., Hedrick R.P. 1991: Lectin histochemistry and ultrastructure of rainbow trout Oncorhynchus mykiss kidneys affected by proliferative kidney disease. Dis. Aquat. Org. 10: 173-183.

El-Matbouli M., Anders C., Hoffmann R.W., Kaltner K., Gabius H.-J. 2002: Detection of glycoconjugates and lectin-like activities in the causative agent of whirling disease. In: J.L. Bartholomew and J.C. Wilson (Eds.), Whirling Disease: Reviews and Current Topics. Symposium 29. American Fisheries Society, Bethesda, MD, pp. 55-60.

Fuchs N., Ingold K., Sonda S., Bütikofer P., Hemphill A. 1999: Detection of surface-associated and intracellular glycoconjugates and glycoproteins in Neospora caninum tachyzoites. Int. J. Parasitol. 29: 1597-1611.

Fuller A.L., McDougald L.R. 2002: Lectin-binding by sporozoites of Eimeria tenella. Parasitol. Res. 88: 118-125.
Ghittino C., Latini M., Agnetti F., Panzieri C., Lauro L., CiapPELLONI R. 2003: Emerging pathologies in aquaculture: effects on production and food safety. Vet. Res. Commun. 27: 471-479.

Golomazou E., Athanassopoulou F., Karagouni E., Tsagozis P., Tsantilas H., Vagianou S.T. 2006: Experimental transmission of Enteromyxum leei Diamant, Lom and Dykova, 1994 in sharpsnout sea bream, Diplodus puntazzo C. and the effect on some innate immune parameters. Aquaculture 260: 44-53.

Griffiths G. 1993: Fine Structure Immunocytochemistry. Springer-Verlag, New York, 459 pp.

Gruden-Movsesijan A., Milosavljevic L.J.S. 2006: The involvement of the macrophage mannose receptor in the innate immune response to infection with parasite Trichinella spiralis. Vet. Immunol. Immunopathol. 109: 57-67.

Hammerschmidt K., Kurtz J. 2005: Surface carbohydrate composition of a tapeworm in its consecutive intermediate hosts: individual variation and fitness consequences. Int. J. Parasitol. 35: 1499-1507.

Hart G.W., West C.M. 2009: Nucleocytoplasmic glycosylation. In: A. Varki, R.D. Cummings, J.D. Esko, H.H. Freeze, P. Stanley, C.R. Bertozzi, G.W. Hart and M.E. Etzler (Eds.), Essentials of Glycobiology. Second Edition. Cold Spring Harbor, New York, pp. 17-1, 17-13.

Hokke C.H., Yazdanbakhsh M. 2005: Schistosome glycans and innate immunity. Parasite Immunol. 27: 257-264.

HorÁK P. 1995: Developmentally regulated expression of surface carbohydrate residues on larval stages of the avian schistosome Trichobilharzia szidati. Folia Parasitol. 42: 255-265.

ImBERTY A., VARRot A. 2008: Microbial recognition of human cell surface glycoconjugates. Curr. Opin. Struct. Biol. 18: 567-576. 
Iyer S.N., Hart G.W. 2003: Dynamic nuclear and cytoplasmic glycosylation: enzymes of O-GlcNAc cycling. Biochemistry 42: 2493-2499.

JACOBSON R.J., Doyle R.L. 1996: Lectin-parasite interactions. Parasitol. Today 12: 55-61.

John N.M., Zea M.E., Kawano T., Omata Y., Saito A., Toyoda Y., Мiкамі T. 1999: Identification of carbohydrates on Eimeria stiedai sporozoites and their role in the invasion of cultured cells. Vet. Parasitol. 81: 99-105.

Kaltner H., Stippi M., Knaus M., El-Matbouli M. 2007: Characterization of glycans in the development stages of Myxobolus cerebralis (Myxozoa), the causative agent of whirling disease. J. Fish Dis. 30: 637-647.

Kim J.H., Ogawa K., WaKabayashi H. 1999: Lectin-reactive components of the microsporidian Glugea plecoglossi and their relation to spore phagocytosis by head kidney macrophages of ayu Plecoglossus altivelis. Dis. Aquat. Org. 39: 59-63.

Klabunde J., Berger J., Jensenius J.C., Klinkert M.Q., Zelck U.E., Kremsner P.G., Kun J.F.J. 2000: Schistosoma mansoni: adhesion of mannan-binding lectin to surface glycoproteins of cercariae and adult worms. Exp. Parasitol. 95: 231-239.

Knaus M., El-Matbouli M. 2005: Characterisation of carbohydrate-binding sites in developmental stages of Myxobolus cerebralis. Parasitol. Res. 97: 505-514.

Lom J., Dyкová I. 2006: Myxozoan genera: definition and notes on taxonomy, life-cycle terminology and pathogenic species. Folia Parasitol. 53: 1-36.

Lukeš J., Volf P., Lom J. 1993: Detection of chitin in spores of Myxobolus muelleri and M. subepithelialis (Myxosporea, Myxozoa). Parasitol. Res. 79: 439-440.

Ma B., Simala-Grant J.L., Taylor D.E. 2006: Fucosylation in prokaryotes and eukaryotes. Glycobiology 16: 158R-184R.

Marín de Mateo M., Bovo G., Comuzzi M., Adams A. 1997: Lectin histochemical studies on Sphaerospora sp. (Myxosporea) from Italian brown trout, Salmo trutta L. J. Fish Dis. 20: 51-58.

Marín de Mateo M., McGeorge J., Morris D., Kent M.L. 1996: Comparative studies of PKX and Sphaerospora spp. from salmonids using lectin and monoclonal antibody staining techniques. J. Fish Dis. 19: 55-63.

Morris D.J., Adams A. 2004: Localization of carbohydrate terminals on Tetracapsuloides bryosalmonae using lectin histochemistry and immunogold electron microscopy. J. Fish Dis. 27: $37-45$.

Muñoz P., Palenzuela O., Álvarez-Pellitero P., Sitjà-BobaDILla A. 1999: Comparative studies on carbohydrates of several myxosporean parasites of fish using lectin histochemical methods. Folia Parasitol. 46: 241-247.

Muñoz P., Sitjà-Bobadilla A., Álvarez-Pellitero P. 2000: Ultrastructural localisation of carbohydrates in several myxosporean parasites. Parasite 7: 185-191.

Padrós P., Palenzuela O., Hispano C., Tosas O., Zarza C., Crespo S., Alvarez-Pellitero P. 2001: Myxidium leei (Myxo-

Received 19 February 2009 zoa) infections in aquarium-reared Mediterranean fish species. Dis. Aquat. Org. 47: 57-62.

Palenzuela O. 2006: Myxozoan infections in Mediterranean mariculture. Parassitologia 48: 27-29.

Quiroga M.I., Redondo M.J., Sitjá-Bobadilla A., Palenzuela O., Riaza A., Macías A., Vázquez S., Pérez A., Nieto J.M., Álvarez-Pellitero P. 2006: Risk factors associated with Enteromyxum scophthalmi (Myxozoa) infection in cultured turbot, Scophthalmus maximus (L.). Parasitology 133: 433-442.

Redondo M.J., Cortadellas N., Palenzuela O., Alvarez-PelLiTERo P. 2008: Detection of carbohydrate terminals in the enteric parasite Enteromyxum scophthalmi (Myxozoa) and possible interactions with its fish host Psetta maxima. Parasitol. Res. 102: 1257-1267.

Rodríguez A., Esteban M.A., Meseguer J. 2003: A mannose-receptor is possibly involved in the phagocytosis of Saccharomyces cerevisiae by seabream (Sparus aurata L.) leucocytes. Fish Shellfish Immunol. 14: 375-388.

Schabussová I., Schabuss M., Gelnar M., Horák P. 2003: Use of lectins in characterizing developmentally regulated changes on the surface of Paradiplozoon megan (Monogenea: Diplozoidae). Helminthologia 40: 135-140.

Sharon N. 2006: Carbohydrates as future anti-adhesion drugs for infectious diseases. Biochim. Biophys. Acta 1760: 527-537.

Sitjè-Bobadilla A., Diamant A., Palenzuela O., AlvarezPellitero P. 2007: Effect of host factors and experimental conditions on the horizontal transmission of Enteromyxum leei (Myxozoa) to gilthead sea bream, Sparus aurata L., and European sea bass, Dicentrarchus labrax (L.). J. Fish Dis. 30: 243-250.

Soeiro M.N.C., Paiva M.M., Barbossa H.S., Meirelles M.N.L., ArÁujo-Jorge T.C. 1999: A cardiomyocyte mannose receptor system is involved in Trypanosoma cruzi invasion and is downmodulated after infection. Cell Struct. Funct. 24: 139-149.

Taupin V., Garenaux E., Mazet M., Maes E., Denise H., Prensier G., Vivarès C.P., Guérardel Y., Méténier G. 2006: Major $O$-glycans in the spores of two microsporidian parasites are represented by unbranched manno-oligosaccharides containing $\alpha-1,2$ linkages. Glycobiology 17: 56-67.

Taylor D.W., Goddard J.M., McMahon J.E. 1986: Surface component on Onchocerca volvulus. Mol. Biochem. Parasitol. 18: 283-300.

Wisnewski N., McNeil M., Grieve R.B., Wassom D.L. 1993: Characterization of a novel fucosyl- and tylevosyl-containing glycoconjugates from Trichinella spiralis muscle stage larvae. Mol. Biochem. Parasitol. 61: 25-36.

Yaganida T., Nomura Y., Kimura T., Fukuda Y., Yokoyama H., OgaWA K. 2004: Molecular and morphological redescriptions of enteric myxozoans, Enteromyxum leei (formerly Myxidium sp. TP) and Enteromyxum fugu comb. n. (syn. Myxidium fugu) from cultured tiger puffer. Fish Pathol. 39: 137-143.

Xu D.-H., Klesius P.H., Shoemaker C.A. 2001: Effect of lectins on the invasion of Ichthyophthirius theront to channel catfish tissue. Dis. Aquat. Org. 45: 115-120.

Accepted 21 July 2009 